\title{
Current Status of Water Hyacinth (Eichhornia crassipes) in Ethiopia: Achievements, Challenges and Prospects: A Review
}

\author{
Nagassa Dechassa* Belay Abate \\ Ethiopian Institute of Agricultural Research, Ambo Agricultural Research Centre, Ambo, Ethiopia
}

\begin{abstract}
Water hyacinth is one of the rapidly spreading aquatic weeds, both globally and in Ethiopia, causing adverse effect on ecosystem and human benefits. It directly and indirectly affects fish, crop and livestock productions, electric power generation, irrigation, waterway transportation, tourism and human health. It is an invasive weed that is native to Amazon basin and introduced as an ornamental species to decorate the water bodies in Ethiopia. The weeds' fastest growth, ways of reproduction, ability to adapt to wide range of climatic conditions and nutrients, and complex root system made its management difficulty. However, Manual removal of water hyacinth in small areas at early time is effective in controlling the weed for short period of time. Use of biological control agents; arthropods (Neochetina brunchi and Neochetina eichhorniae) and parasitic fungi (Alternaria alternata, Alternaria $s p$., Alternaria tenuissima and Neofusicoccum parvum) play a role in controlling specifically water hyacinth in Ethiopia at experimental level. In addition Chemical control with 2, 4-D dimethyl amine, glyphosphate and acetic acid are effective to control water hyacinth in extreme cases. Integrated use of herbicidal and mechanical control measures is effective in control, economically safe and environmentally friendly than a single control measures. Weed removing machines and integrated managements should be designed based on Ethiopian water bodies' conditions in the future research. The release of promising biological control agents should be encouraged by the Ethiopian government.
\end{abstract}

Keywords: Alien weeds, Aquatic weeds, Ethiopia, Invasive weeds, Neochetina spp.,

DOI: $10.7176 / \mathrm{JEES} / 10-12-03$

Publication date: December $31^{\text {st }} 2020$

\section{Introduction}

In Ethiopia, 35 alien invasive weed species are posing negative impacts on native biodiversity, agricultural lands, range lands, national parks, water ways, lakes, rivers, power dams, road sides, and urban green spaces with great economic and social consequences (Rezene and Taye, 2014). Among these species Eichhornia crassipes, Parthenium hysterophorus, Prosopis julifilora, Lantana camara and Mimosa spp. are the most widely spreading and invading weeds in Ethiopia.

Water Hyacinth (Eichhornia crassipes (Mart.) Solms) is one of the world's worst invasive, perennial, herbaceous, free-floating, aquatic weed due to its ability to rapidly cover whole waterways. It was discovered and named as Pontederia crassipes in 1823 by the German naturalist Martius (Martius et al., 1823). Solms (1883) renamed this species Eichhornia crassipes in 1883. The weed is an invasive plant that is native to Brazil, Amazon basin and Ecuador region (Gopal, 1987; Hill and Coetzee, 2008). The weed was introduced as an ornamental species to decorate the water bodies in many countries for their attractive blue or purple flowers, oblong to oval glossy leaves with bulbous petioles (Tellez et al., 2008). It forms thick floating mats on the water surface that tends to reduce sunlight penetration and the exchange of gases between the water surface and the atmosphere (Ceschin et al., 2019). Starting from the Amazon basin reached many tropical and sub-tropical countries of Latin America, the Caribbean, Africa, Southeast Asia, and the Pacific (Julien, 2000; Navarro and Phiri, 2000). Similar Authors indicated that freshwater bodies, swamps and wetland areas of Africa and the Middle East have been remarkable invaded by this invasive weed.

In Ethiopia, Water hyacinth was first reported in 1956 in Koka Lake and Awash River (Stroud 1994). It is known as "Emboch" in Amharic or "Bocee" in Afan Oromo, in Ethiopia with its disruptive impacts on aquatic ecosystems, agriculture, fisheries, transportation, living conditions and social structures in the country. The weed was less recognized on water bodies in the late 1956 to late 2011; but, as presented in earlier reports and articles, it became prevalent and economically important in water bodies of Ethiopia (Firehun et al., 2013; Wondie, 2013; Tegene and Ayele, 2014). Therefore, the objective of this paper is to review the current status of water hyacinth, achievements, challenges, and future prospects of water hyacinth in Ethiopia. 


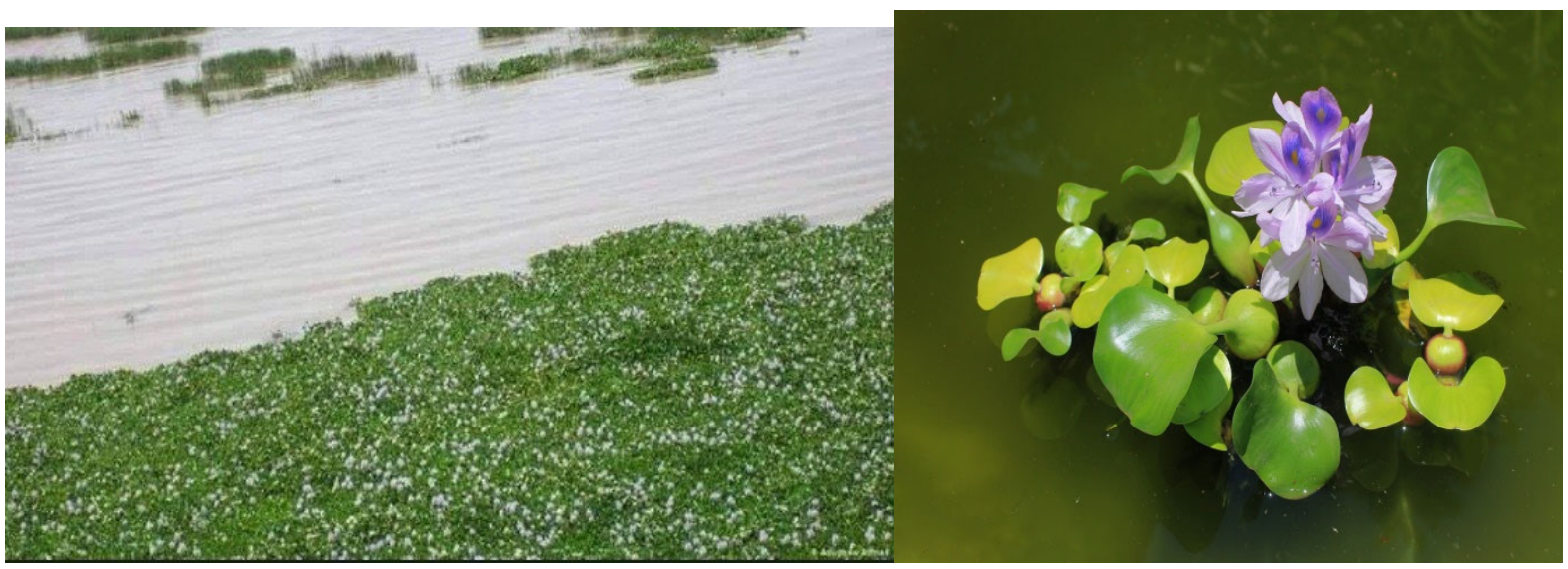

Figure 1. Water hyacinth infestation on water bodies in Ethiopia.

\section{Body of the Text}

\subsection{Status of Water Hyacinth in Ethiopia}

Water hyacinth infestation in Ethiopia has been manifested on a large scale in many water bodies of the country. The weed spreads frequently and reproduces quickly. Based on favorable conditions, it doubles its area coverage every 6 to 15 days (Keller and Lodge 2009). In Ethiopia, Water hyacinth was first reported in 1956 in Koka Lake and the Awash River as a decorative plant and from there it started to spread to other nearby water bodies (Firehun et al., 2017; Wondie, 2013; Tegene and Ayele, 2014). It was less recognized weed of water bodies in the late 1956 to late 2011; but, as presented in earlier reports and articles, it became prevalent and economically important (Firehun et al., 2013; Wondie, 2013; Tegene and Ayele, 2014). The introduction and rapid spread of this weed in the Awash River Basin (Koka Lake, Koka Dam), Abay River Basin (Lake Tana, Blue Nile), Baro-Akobo River Basin (Sobate, Baro, Gillo and Pibor rivers) and Rift Valley Basins System (Lake Ellen, Lake Abaya, Lake Elltoke), has created serious problems for the use of the water as a resource (Senayit et al., 2004; Rezene, 2005; Taye et al., 2009).

As shown in the figure, water hyacinth infested only 50.5ha of the surface of Lake Tana, and limited to one kebele located around the mouth of Megech River in last month of 2012. Currently, the weed infestation increases in space and time and infested about 30 kebeles in nine districts (Takusa, West Dembia, East Dembia, Gonder Zuria, Libokemkem, Fogera, Dera, Bahir dar zuria) (BDU, 2020). The rate of weed infestation decreased from November 2013 to October 2015 and January to June of 2020 due to human mobilization in manual removal of the weed.

The ability of the weed to grow very fast and its adaptation to a wide range of environmental condition and nutrients as a whole brings about shift in the status of the weed in sporadic time and space in Ethiopia. The emergence and increasing rate of the weed is associated with many factors, (1) means of reproduction (both by stolon and seed); (2) its fastest growth; (3) Adaptation to a wide range of nutrient and environmental conditions; (4) its complex root structures (5) its seed persistence in the water for long period of time 25-30 years (Patel, 2012). 


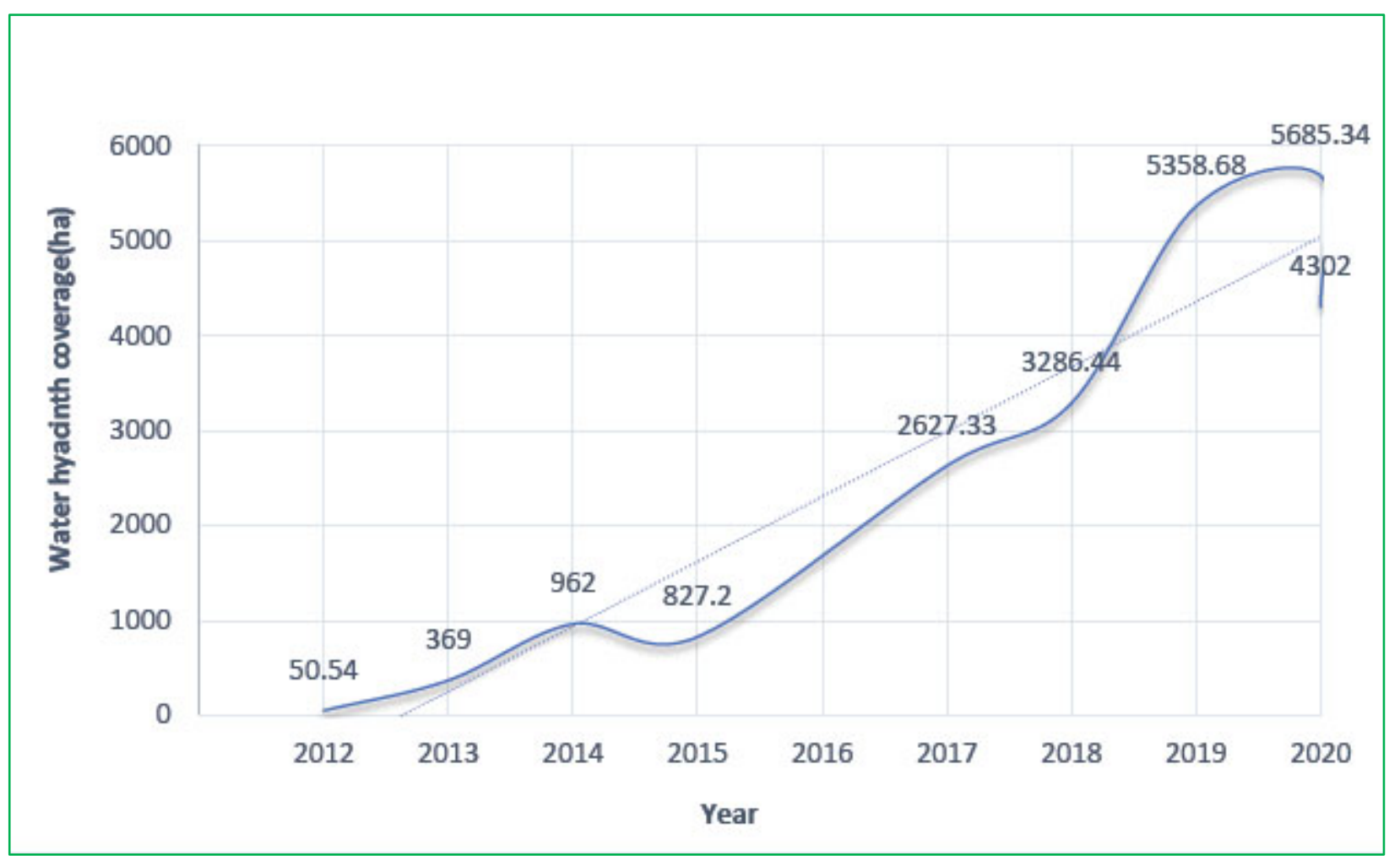

Figure 2. The spatiotemporal dynamics of water hyacinth infestation on Lake Tana from 2012 to 2020. Source: BDU, 2020.

\subsection{Economic Importance of water hyacinth}

Mats block light from penetrating water bodies, which induces changes in the flora and fauna underneath, sometimes hindering fish production and resulting in unemployment and diminished incomes and food for riparian communities due to the fact that local plants and animals lose their habitats and the quality of drinking, cooking and washing water deteriorates. There are even reports of village people dying from the problems of heavy water hyacinth infestation; 1) People have died from starvation because they could not reach food sources; 2) Bites of venomous snakes hiding in water hyacinth mats; 3 ) Attacks by crocodiles taking shelter in water hyacinth mats; 4) Diseases carried by mosquitoes (malaria) or snails (bilharzia) that breed in water hyacinth environments; and 5) Fatigue from pushing canoes through clogged waterways (Navarro and Phiri, 2000).

\subsubsection{Effect of Water Hyacinth on Fish Production}

Habitat modification and habitat complexity made by water hyacinth at the surface of the water restrict the growth of other submersed microorganisms and affect fishes and other invertebrates. Mats of water hyacinth greatly affect fish catch rates by blocking access to fishing grounds clogging and damaging eye of net and increasing costs of fishing. It also increases cost of fishing by tearing gill nets and damage boats motor.

Mats of water hyacinth suppress the algae growth and development which is the main source of food for fishes by preventing enough sunlight and oxygen penetration. It also reduced the potential of fish production of Lake Tana from 13,000 tons a year to 1,000 tons a year. The potential fish production of the lake is estimated to be 13,000 tons yearly. But its current fish production is less than 1000 tons a year. Recent studies show a serious decline in fish stocks due to the spread of the aquatic weed water hyacinth around fish spawning grounds. 

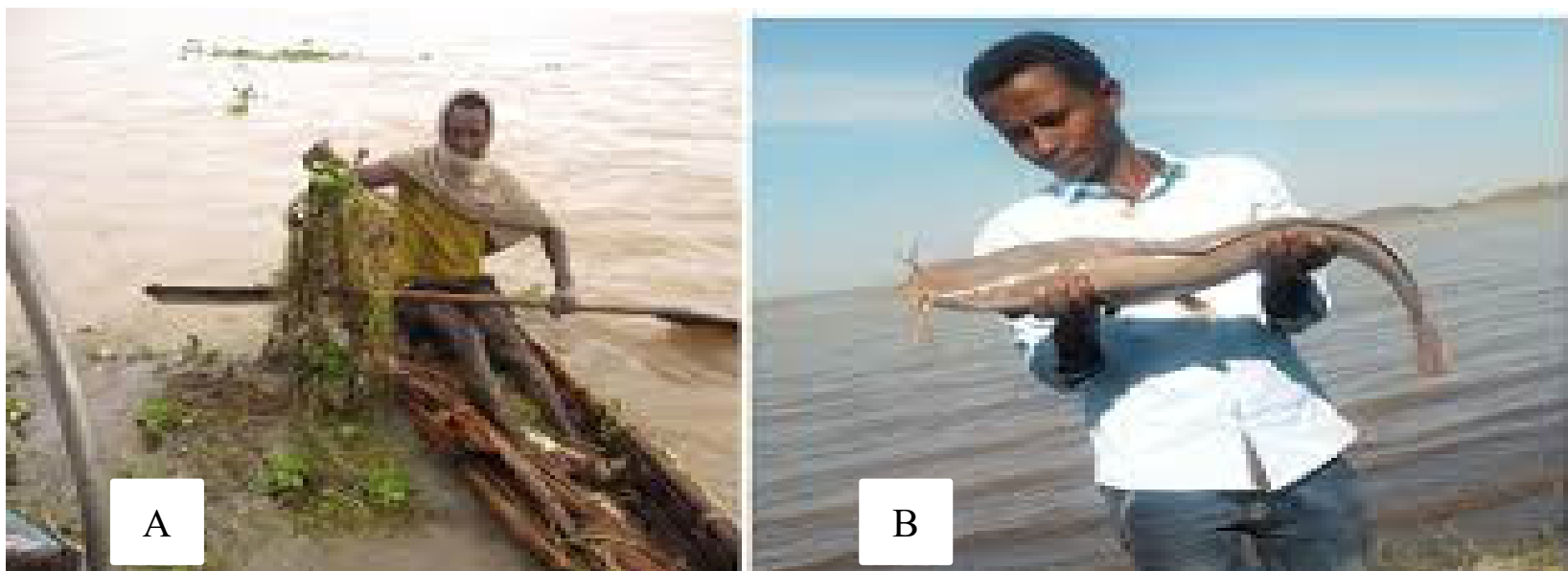

Figure 3. A) Fishing net entangled by water hyacinth at the landing site, B) fishing at area free from water hyacinth. Source: Asmare, (2017).

\subsubsection{Effects of Water Hyacinth on Livestock}

Mats of water hyacinth affect livestock production around Lake Tana by suppressing submerging grasses (hippo grass) which feeds lots of cattle for the surrounding inhabitants. Reports indicated that the tropics of Lake Tana (Dambia and Fogera districts) highly devastated by the spread of Water Hyacinth and thousands of hectares of wet land, pasture and agricultural land have been ineffective. Fogera breeds most dominantly produced at Dambia and Fogera districts highly decreased their milk and milk by products as a result of the devastation of this weeds (EBI, 2019).

Similar report indicated that Water Hyacinth weed highly invaded and destroyed variety of grass species grown on the shoreline of Koka Dam and Lake Zeway, and as a result the grazing land has been substantially reduced, creating a serious challenge, on the community, who are engaged in cattle breading (EBI, 2019). It also caused shortage of animal and human drinking water and blockage of irrigation canals.

According to Enyew et al. (2020) feeding of water hyacinth caused gut bloating and continuous diarrhea on livestock. The stalk tissues of water hyacinth contain intercellular spaces filled with air which is the principal factor for the bloating of ruminant guts and continuous diarrhea to the livestock feeding from the weed (Enyew et al., 2020). It also increases the intensity of breeding of leech and other internal parasites in the lake and associated marshlands which contributed to the loss of body weight and death of livestock.
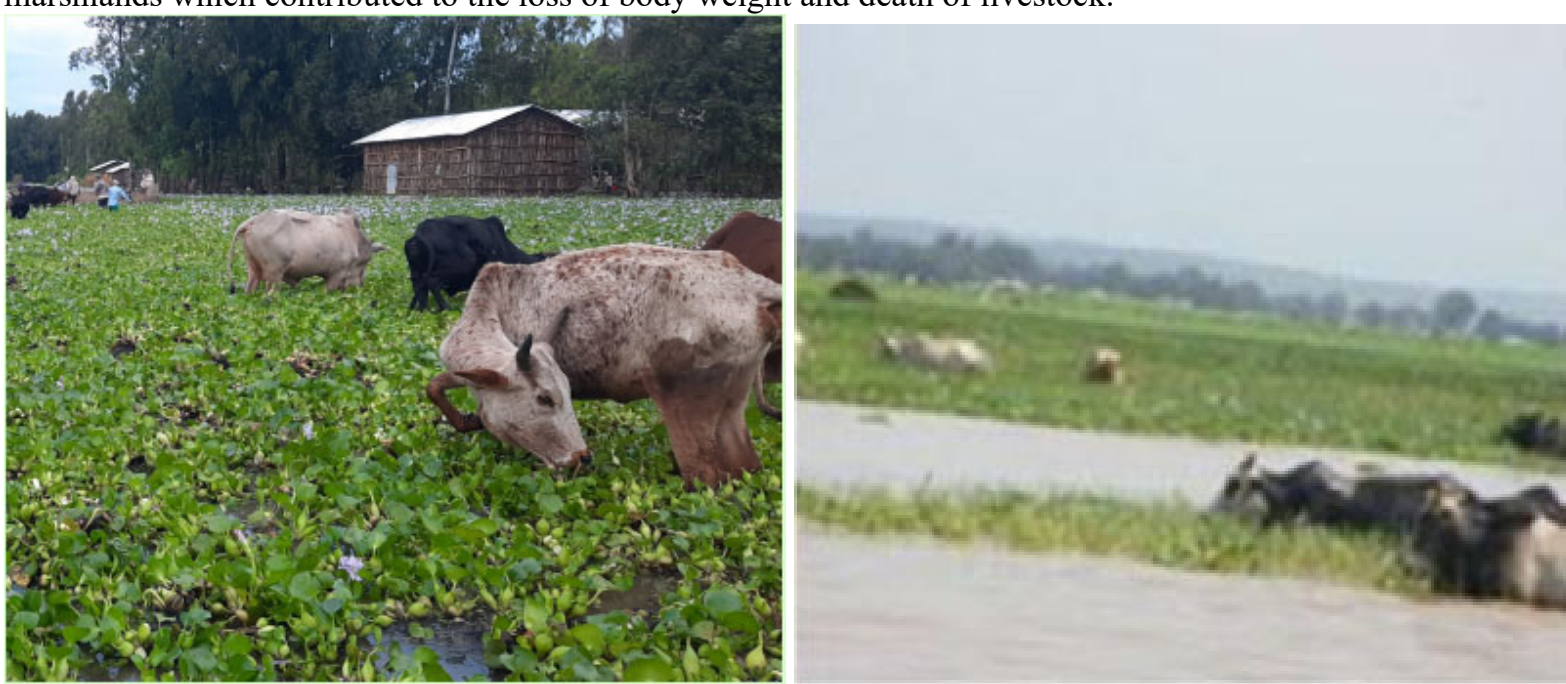

Figure 4: The impact of Water Hyacinth on cattle grazing Land, at Fogera District near Lake Tana.

\subsubsection{Effects of Water Hyacinth on Crop Production}

Water hyacinth has negative effect on paddy crop production. It destroys the plant by inhibiting germination, and interfering with harvesting. Mats of water hyacinth make rice production frustrating by totally covering the crop field during flooding and wave time. It makes the farmland more compacted due to its long root and makes the farmland difficult to plough. The water hyacinth heap has also a noticeable impact on farm management because they took large places and make the farmland fragile (Tewabe et al., 2016). 

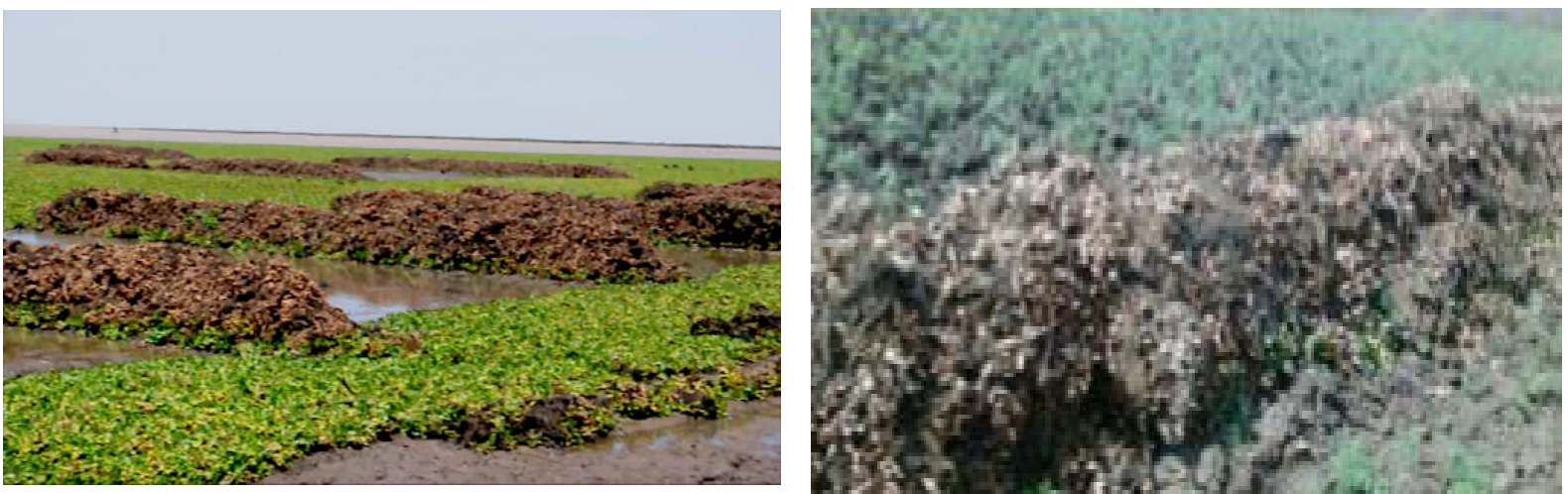

Figure 5. Heap of Water Hyacinth affecting Rice production on wetlands near Lake Tana

\subsubsection{Effects of Water Hyacinth on Human Health and Recreation}

There are reports of village people dying from the problems of heavy water hyacinth infestation; 1) People whose livelihood depends on fish have died from starvation because they could not reach food sources; 2) Bites of venomous snakes hiding in water hyacinth mats; 3) Attacks by crocodiles taking shelter in water hyacinth mats; 4) Diseases carried by mosquitoes (malaria) or snails (bilharzia) that breed in water hyacinth environments; and 5) Fatigue from pushing canoes through clogged waterways (Navarro and Phiri, 2000; Degaga, 2019). Swimming in the lake and river mouths is not also possible especially during the peak infestation seasons of water hyacinth.
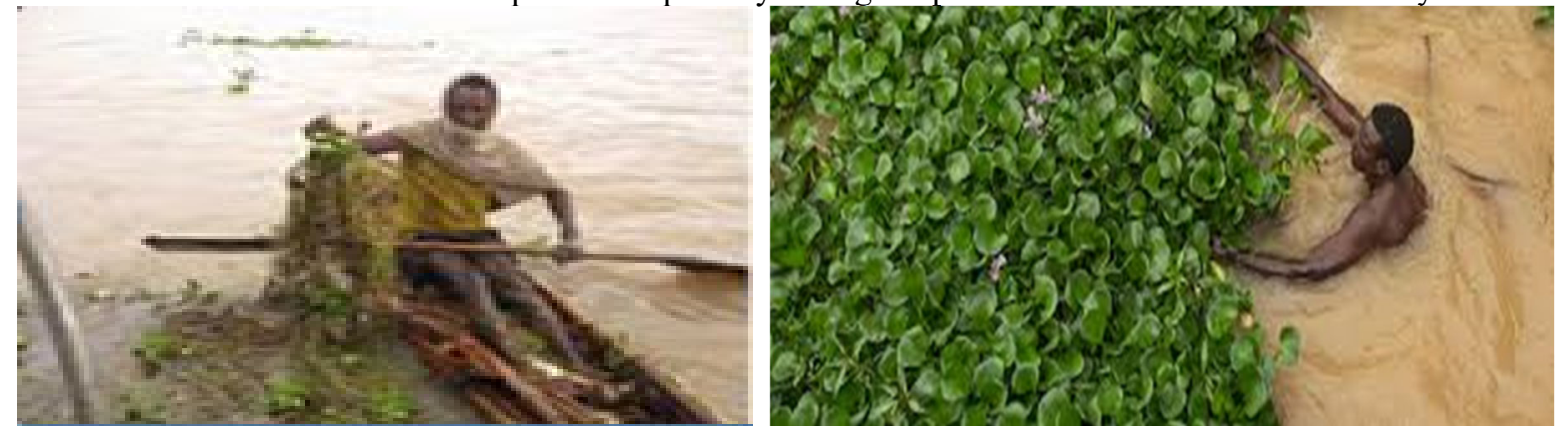

Figure 6. Water Hyacinth affecting human recreation (swimming).

\subsubsection{Effects of Water Hyacinth on Ecosystems and Biodiversity}

Mats of water hyacinth block light from penetrating water bodies, which induces changes in the flora and fauna underneath due to the fact that local plants and animals lose their habitats (Meerhoff et al., 2003). It also deteriorates the quality of drinking, cooking and washing water. The weed invasions change the natural diversity and balance of ecological communities by out-competing all other species growing in the vicinity and posing a threat to aquatic biodiversity. Besides suppressing the growth of native plants and negatively affecting microbes, it inhibits the growth and abundance of phytoplankton under large mats through lowering dissolved oxygen concentrations, ultimately affecting organisms feeding on phytoplankton like fishes. Reduced phytoplankton productivity can decrease zooplankton abundance by decreasing food availability (Stasio et al., 2018).

Water hyacinth also affects diversity, distribution, and abundance of life in aquatic environments and enhances evapotranspiration, thus affecting all aquatic organisms. The death and decay of water hyacinth vegetation in large masses create anaerobic conditions and production of lethal gases (Tewabe et al., 2017). Coverage of water hyacinth causes de-oxygenation of water, and at times anoxia below the dense mats (Tewabe et al., 2017).

\subsubsection{Effects of Water Hyacinth on Waterway Transport and Tourism}

It is obvious that the occurrence of high prolific water hyacinth in water ways has greatly affect the lives of the riverine people in many developing countries of Africa. The thick mat of water hyacinth trapped water way shipment transporting tourists, traders and goods in Ethiopia which causes adverse effect on trade, transport and tourism sectors. 


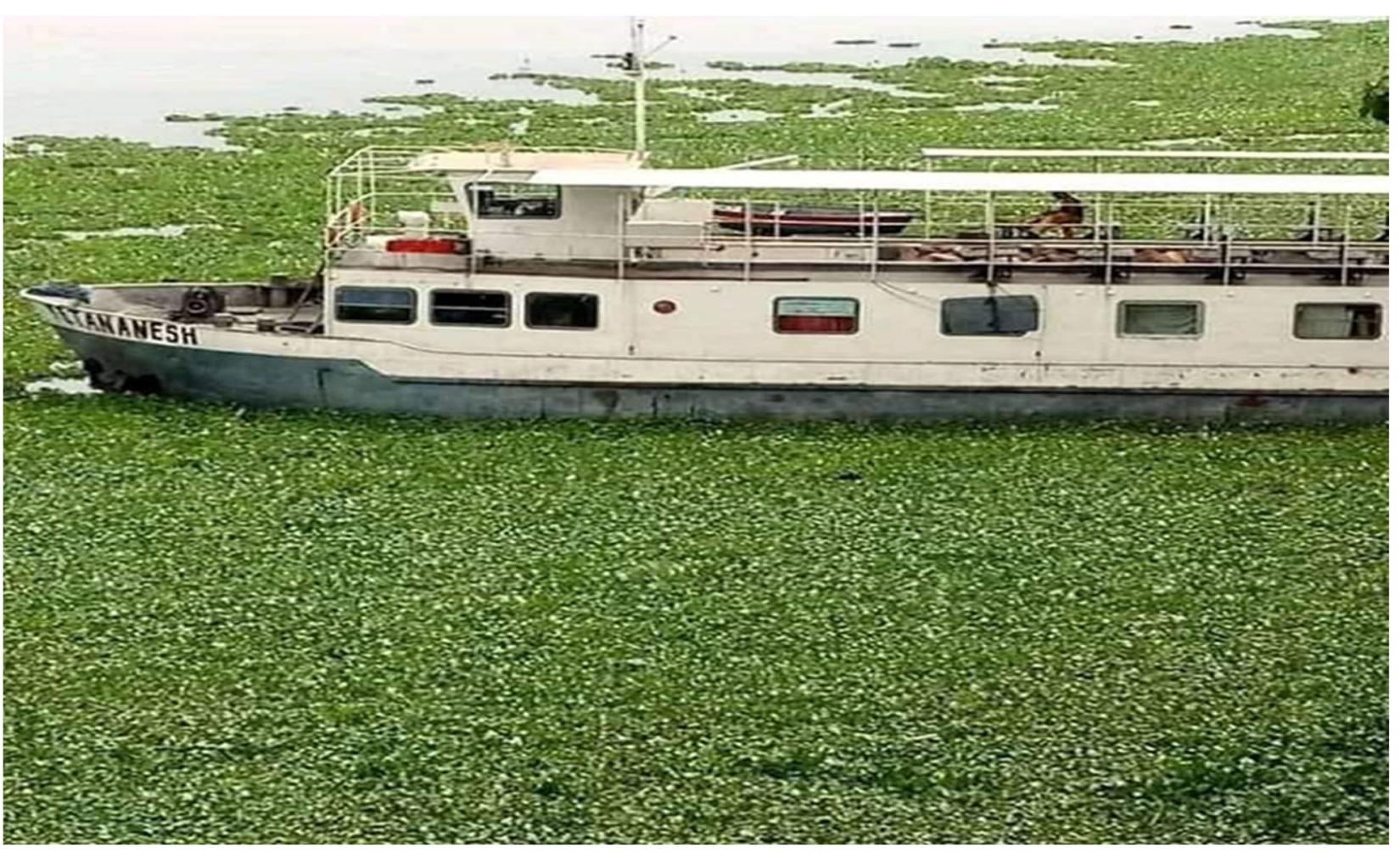

Figure 7. Water Hyacinth affecting water way transportation

\subsubsection{Effects of Water Hyacinth on Water supply, Electricity and Irrigation}

The infestation of water hyacinth on lakes, river mouths and swamps affects quality and quantity of water used for human drinking, livestock watering, washing clothes, and baths. According to Enyew et al. (2020), the weed blocked the digging of boreholes and fetching of water for drinking and cooking from the lake and river mouths. Hence, Livestock watering has been difficult for herders due to the blockage of the weed and poor odor of water. The largest surface area of the weed increases the evapotranspiration rate which affects the hydrologic balance of water bodies.

Disrupting hydro-electric power generation, blockage of irrigation canals and rivers, and interference with irrigation activities are also the major problem of water hyacinth infestation (Taye et al., 2009). Currently it is a great fear of many Ethiopian naturalists and scientists for the Ethiopia Great Renaissance Dam (EGRD) project because of the fact that the weed spreads by seeds and stolons from the upstream to downstream and established the water bodies very fast.

\subsection{Control Measures of Water Hyacinth}

Considering the impact of water hyacinth in Ethiopia, many scholars investigated certain management options. The most appropriate management strategy for the weed depends on the nature, site and use of waterway, level and age of weed infestation, climate and presence or absence of an upstream infestation. Also current and ongoing resources available to control the weed need to be considered in the control and management of water hyacinth. Several controlling mechanisms are available which include biological, physical (mechanical and manual removal), chemical control and integration of two or more control measures.

\subsubsection{Biological Control of Water Hyacinth}

Biological control is the most cost effective and environment friendly control method in controlling water hyacinth. The types of organisms that can be deployed as biological control agent range from the very minutes, such as pathogenic fungi and through herbivorous weevils like the Neochetina species. It is the most economical and sustainable method of control because it persists with little ongoing cost and no negative environmental impacts (Julien et al. 1999).

\subsubsection{Herbivorous Weevils}

Studies indicated that water hyacinth growth and reproduction is reduced by herbivorous weevils. Up to a date about eight arthropod agents (Neochetina brunchi, Neochetina eichhorniae, Niphograpta albiguttalis, Orthogalumna terebrantis, Eccritotarsus catarinensis, Xubida infusellus, Cornops aquaticum and Thrypticus spp.) were released in many countries for the control of this weed (Julien et al., 1998; Tipping et al., 2014). Among these arthropod, two weevils, Neochetina eichhorniae and Neochetina bruchi, are the most effective in controlling the weed worldwide (Center et al., 1999; Center and Van, 1989). N. bruchi and N. eichhorniae have been released 
on water hyacinth in 30 and 27 countries, respectively (Center et al., 2002).

Ethiopian Institute of Agricultural Research in collaboration with Wanji sugar factory imported two Neochetina weevil species (Neochetina eichhorniae and Neochetina bruchi) from Uganda to Ethiopia following the quarantine procedures of the country. In Ethiopia, the two weevils are well adapted, successfully established and produced four generations per year (Firehun et al., 2017). These weevils were reared and evaluated against water hyacinth at Wonji research station. Feeding by adult weevils and tunneling by larvae significantly impacted the vigor and reproduction of water hyacinth. These weevils are host specific and successful biological agents used for the control of water hyacinth. Thus, based on their damage potential and difference in rate of population growth, Firehun et al., (2015) concluded that $N$. bruchi is a promising candidate for biological control of water hyacinth under Ethiopian conditions. The weevils involved in biological control of the weed also facilitate the transfer and ingress of deleterious microorganisms (both fungi and bacteria) associated with the weevils into the plant tissues (Van et al., 2010).
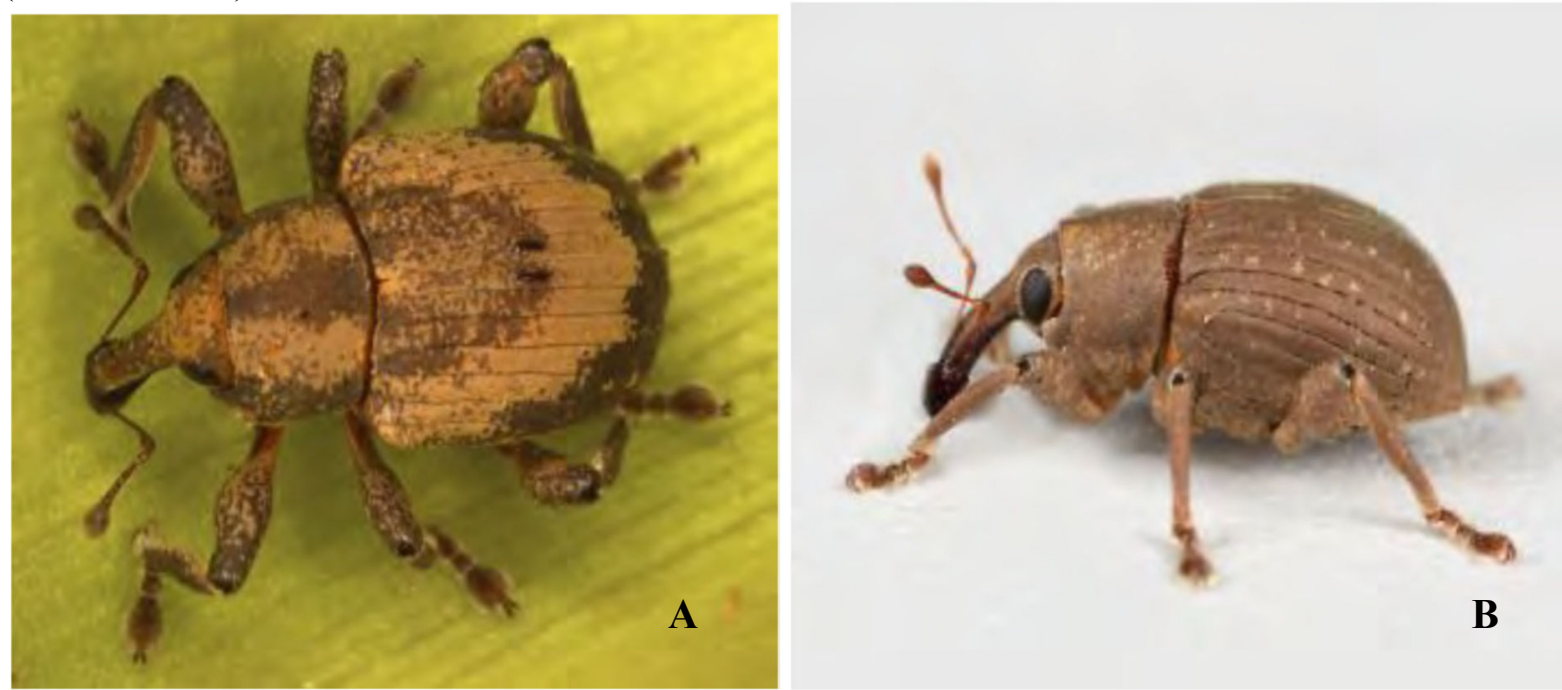

Figure 8. Herbivorous weevils as biological control agents A) Neochetina bruchi B) Neochetina eichornia

\subsubsection{Fungal pathogens}

Many fungal pathogens have the potential to infest and reduce the growth and population of water hyacinth. In Ethiopia, Firehun et al. (12017) reported that about 10 (ten) fungal species (Alternaria sp., Alternaria tenuissima, Alternaria alternate, Curvularia trifolii, Mucor fragilis, Phoma macrostomata, Neofusicoccum parvum, Fusarium equiseti, Fusarium oxysporum and Botryosphaeria sp.) are negatively associated with growth and development of the weed. The highest disease incidence and severity caused by these pathogens reduce the weed (fresh and dry) weight, plant height, root length and reproduction of water hyacinth (Firehun et al., 12017). In Ethiopia the reduction in weed fresh weight, dry weight, plant height and root length caused by the infestation of these pathogens ranged $11-67 \%, 22-72 \%, 15-55 \%$, and 12-50\%, respectively (Firehun et al., 2017). The pathogenic fungal pathogens observed in the present study have also been reported from other countries (El-Morsy, 2004; Ray, 2006). The infestation by these fungal pathogens exposes the weed crowns and leaf petioles to rotting and water logging.

With regarding to the host specificity, Fusarium equiseti and F. oxysporum, are pathogenic to agricultural crops whereas A. alternata, Alternaria sp., A. tenuissima and $N$. parvum) are pathogenic to water hyacinth and water lettuce (Firehun et al., 2017; Rhomela et al., 1999). However, El-Morsy et al. (2006) described A. alternata as a worldwide pathogen of water hyacinth. 

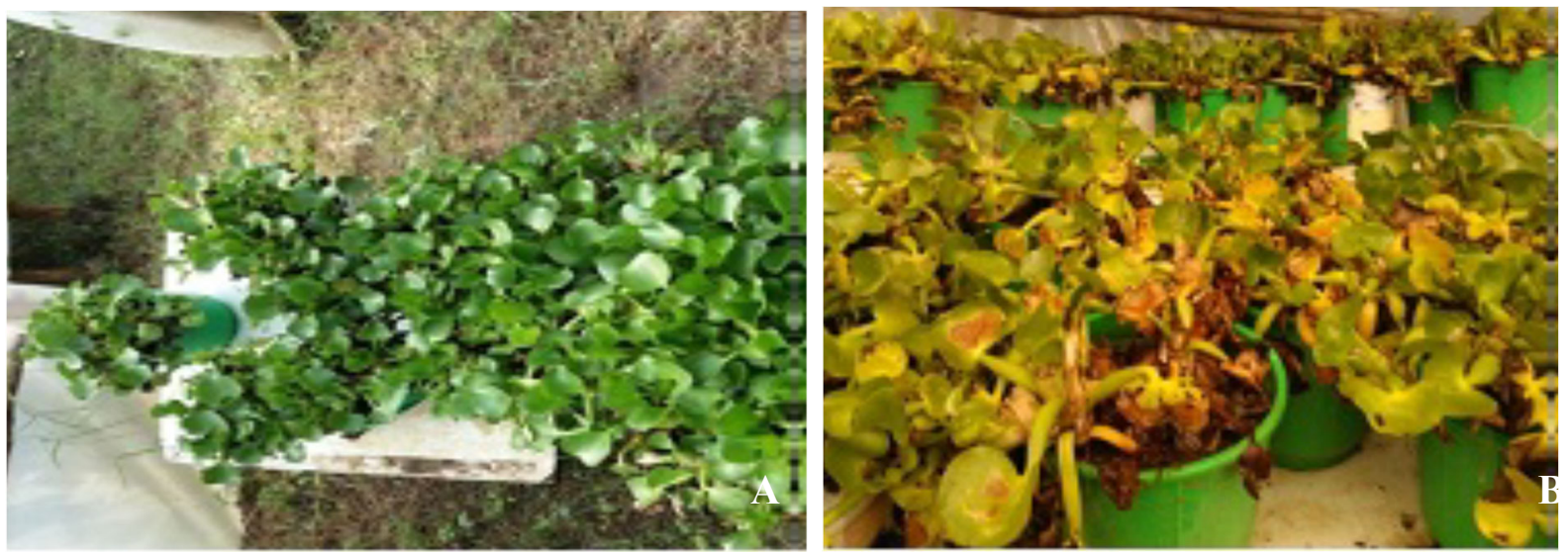

Figure 9. Biological control of Water hyacinth at greenhouse A) Control (untreated) B) Treated by fungus, Source: Admas et al., (2017).
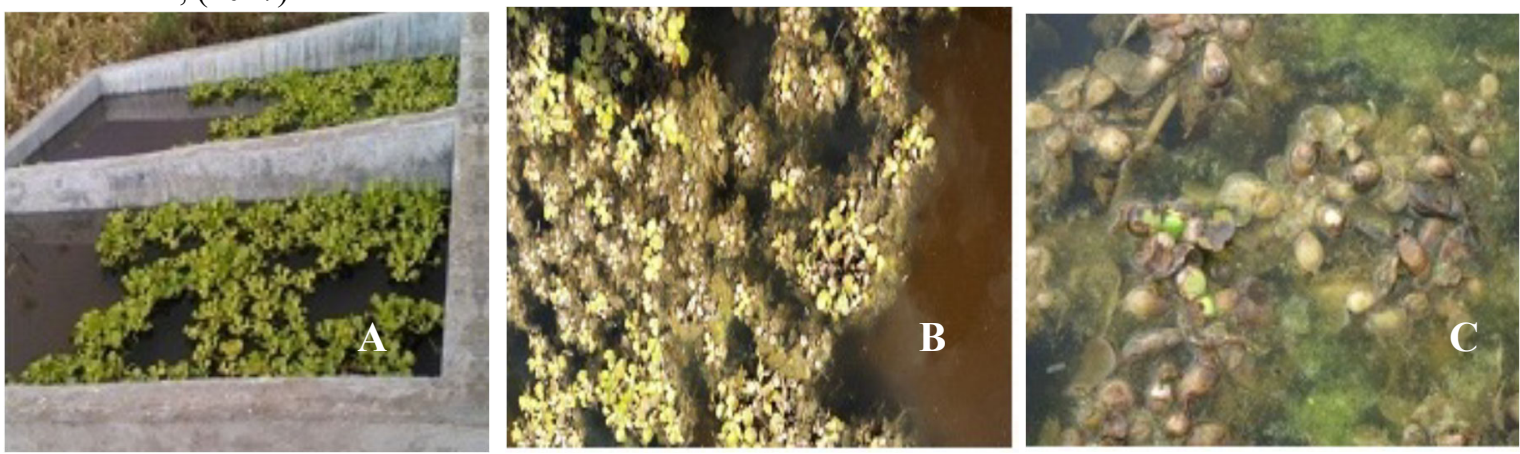

Figure 10. Biological control of Water hyacinth in the pond A) Control (untreated) B-C) Treated by fungus, Source: Admas et al. (2017).

\subsubsection{Physical or Mechanical Water Hyacinth Control Method}

\subsubsection{Physical Water Hyacinth Control Method}

Manual removal of water hyacinth is suitable for extremely small areas but ineffective for large infestations control. Early control attempts concentrated on removing the plant from water with hand or instrument like pitchforks, then dumping the accumulated mass on land to die. However, it is difficult, labor intensive work and in some areas there is serious health risks associated with the workers (crocodiles, hippopotamus, snakes, mosquitoes and bilharzia). Transportation of the harvested weed is also costly, because it has such high water content. Chopping can reduce the volume and the water content. In Ethiopia to manually remove the weed in Lake Tana, more than 800,000 human labor had been dedicated from 2012 to 2018 (Enyew et al., 2020). However the weed is still uncontrolled in the lake. Firehun et al., (2017) concluded that the integration of manual removal and mechanical control measures should be implemented to control water hyacinth.

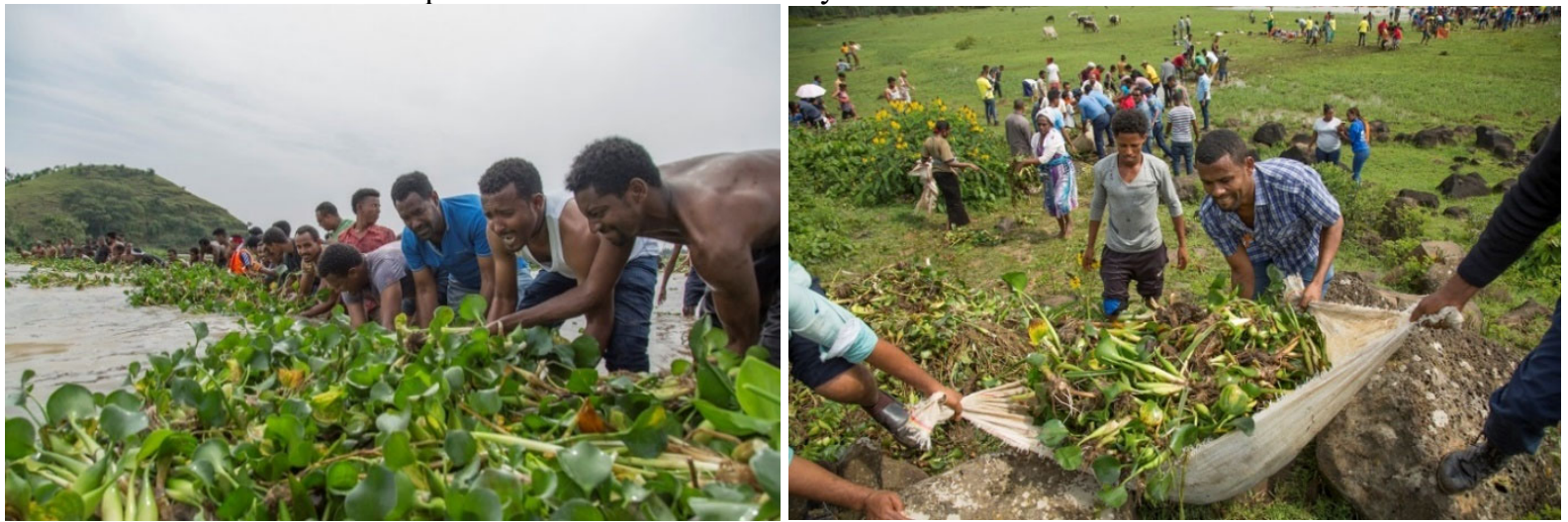

Figure 11. A group of men and women removing water hyacinth from Lake Tana.

\subsubsection{Mechanical Water Hyacinth Control Method}

Mechanical removal of water hyacinth is the best short term solution in controlling the proliferation of the weed in small areas. However, Ethiopia is not successful in controlling the weed by harvesting machines due to; 1) the weed infestation is beyond the capacity of the machine, 2) muddy and clay nature of most of Ethiopian lakes, 3) breakage of harvesting machine with in a short period of time, 4) incapability of Ethiopia to buy harvesting 
machine with harvesting capacity, and 5) skill gap of the use of machine (EBI, 2019).
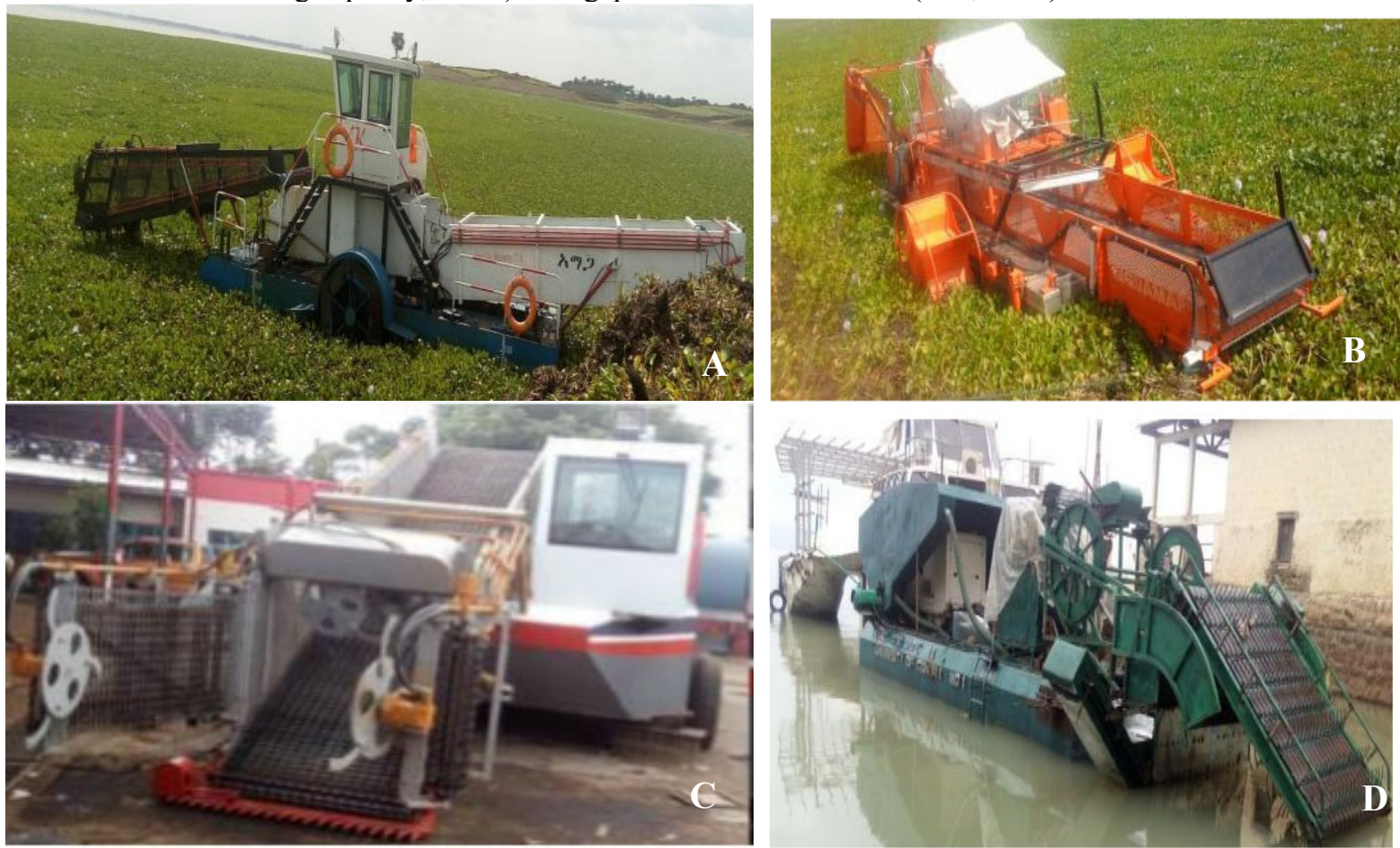

Figure 12. Un-functional Water Hyacinth harvesting Machines in Ethiopia: A) Donated by Amaga p.l.c. B) Donated by the International Tana Safety Association, a Diaspora Ethiopian community association C) Developed by Bahir Dar University and Mulat Engineering p.l.c. D) Developed by Gondar University. Source: EBI, 2019.

\subsubsection{Chemical Control Measures}

Many herbicides were used for the control of water hyacinth among which Paraquat, 2, 4-D acid, and Glyphosate are widely used in Africa with no adverse effect on fish population (Adekoya 2000). Similarly, Agidie 2018 concluded that Glyphosate and acetic acid are effective in controlling water hyacinth in Ethiopia at shade level. This method of control is quickest and cheapest as compared to mechanical and manual control techniques but it requires a select skill to be efficient. The chemical may have negative impact on environment, applicants and nontarget organisms if the considerations are not taken. Among the weed control options this one is the least desirable.

\subsubsection{Integrated Water Hyacinth Management}

An integrated use of herbicidal and mechanical control measures implemented in Wonji shoa sugar factory resulted in better control of the weed than physical control measures especially in the reservoirs, irrigation supplies and drainage systems (Dula et al., 2008). In Ethiopia two (manual removal and mechanical) control measures have been implemented to control water hyacinth and more recently attempts have been made to integrate these control methods (Firehun et al., 2017).

\section{Conclusions}

Similar to anthropogenic introduction of insect pests and other alien and invasive weed species, and climate change, the wickedest water hyacinth becomes a big threat for water bodies worldwide. It is native to South America and extremely invaded many tropical and subtropical countries of all the continents. When the weed is away from its center of origin, it is also away from its natural enemies and has the capacity to quickly multiply and spreads over the continents. Since its first occurrence, the population of this aquatic weed is increasing at an alarming rate which poses serious socioeconomic and environmental problems for millions of people in riparian communities in Ethiopia.

Reduction of fish, crop and livestock production, interference of electric power generation, irrigation activities, waterway transportation, tourism and negative impact on human health are the major economic impacts of the weed. Ethiopia lost many millions of USD in controlling water hyacinth from severely invaded lakes and rivers in the country per year. The effects of the weed are dependent on the extent of the invasion, the uses of the impacted water body, and the controlling methods used.

The weed's fastest growth, ways of reproduction, ability to adapt to wide range of climatic conditions and nutrients, and complex root system made its management difficulty. However, Manual removal of water hyacinth in small areas at early time is effective in controlling the weed for short period of time. Use of biological control agents; arthropods (Neochetina brunchi and Neochetina eichhorniae) and parasitic fungi (Alternaria alternata, 
Alternaria sp., Alternaria tenuissima and Neofusicoccum parvum) play a role in controlling specifically water hyacinth in Ethiopia at experimental level. In addition chemical control with 2, 4-D dimethyl amine, glyphosphate and acetic acid are effective to control water hyacinth in extreme cases. Integrated use of herbicidal and mechanical control measures is effective in control, economically safe and environmentally friendly than a single control measures.

\section{The Way Forward}

Since the present status of water hyacinth is remarkably on increasing trend, it is recommended to:-

1) Carry out successive surveys of Aquatic alien invasive weeds in all water bodies across the country to have a complete picture on the importance of the weeds across water bodies.

2) Detect and monitor early since they are critical for the management of water hyacinth, as successful eradication or suppression is normally only possible when infestations are small. This is also essential to avoid re-establishment and further spread from the soil seed bank

3) Establish public education programs and information center to increase awareness on the importance of the preventative approach in addressing the threats posed by aliens and invasive weed species.

4) Design the water hyacinth removing machines based on the nature, site and use of waterway, level and age of weed infestation, climate and presence or absence of an upstream infestation.

5) Develop integrated water hyacinth controlling mechanisms instead of using a single method.

6) The release of promising biological control agents (Neochetina brunchi and Neochetina eichhorniae) should be encouraged by the Ethiopian government.

\section{References}

Adekoya B (2000). Chemical control of water hyacinth(Eichhornia crassipes at Ere, Ogun State, Nigeria: Implications for Aquatic and Terrestial Biodiversity Conservation.Paper presented at the International conference on water hyacinth, held at New Bussa, Nigeria.

Admas A Sahle S Belete E Agidie A Alebachew M (2017). Controlling Water Hyacinth in Lake Tana Using Biological Method at Green House and Pond Level. Eur Exp Biol. 7 No. 5:30.

Agidie A Samuel S Adugna, A and Mhari A (2018). Controlling water hyacinth, Eichhornia crassipes (Mart.) Solmsusing some selected eco-friendly chemicals. Journal of Aquaculture Research and Development, 9(1):521.

Asmare E (2017). Current trend of water hyacinth expansion and its consequence on the fisheries around North Eastern part of Lake Tana, Ethiopia. Journal of Biodiversity \& Endangered Species, 5(2): 189.

BDU (Bahir Dar University) (2020). Water Hyacinth: a threat to Lake Tana. Geospatial Data and Technology Center (GDTC) in collaboration with V/President for Research \& Community Services Office. Bahir Dar, Ethiopia, October 2020. pp. 15.

Center T and Van T (1989). Alteration of water hyacinth (Eichhornia crassipes) leaf dynamics and phytochemistry by insect damage and plant density. Aquat. Bot. 35:181-195.

Center T Dray J Jubinsky F and Grodowitz M (1999). Biological control of water hyacinth under conditions of maintenance management: can herbicides and insects be integrated? Environ. Manage. 23 (1): 241-256.

Center T Hill M Cordo H and Julien M (2002). Water hyacinth. In: Van Driesche R, Lyon S, Lossey B, Hoddle M and Reardon R (Eds.), Biological Control of Invasive Plants in the Eastern United States. USDA Forest Service, Morgantown, WV, pp. 41-64.

Ceschin S Abati S Traversetti L Spani F Del Grosso F and Scalici M (2019). Effects of the invasive duckweed Lemna minuta on aquatic animals: evidence from an indoor experiment. Plant Biosystems-An International Journal Dealing with all Aspects of Plant Biology, 153 (6): 749-755.

Degaga A (2019). Water Hyacinth (Eichhornia crassipes) Biology and its Impacts on Ecosystem, Biodiversity, Economy and Human Well-being.

Dula A Taye T and Firehun Y (2008). Efficacy of integrated water hyacinth (Eichhornia crassipes) management strategies at Wonji-Shoa sugar factory. Eth. J. Weed Manage. 2 (1): 45-58.

EBI (Ethiopian Biodiversity Institute) 2019. Performance Audit Report of The Auditor General on the Ethiopian Biodiversity Institute's Action on the Management of Invasive Alien Weed Known as Water Hyacinth (Eichhornia Crassipses). Addis Abeba. Addis Ababa, Ethiopia February, 2019. pp. 60

El-Morsy M (2004). Evaluation of microfungi for biological control of water hyacinth in Egypt. Fungal Diver. 16 (1): $35-51$.

El-Morsy M El-Dohlob S Hyde K (2006). Diversity of Alternaria alternata a common destructive pathogen of Eichhornia crassipes in Egypt and its potential use in biological control. Fungal Diver. 23 (1):139-158.

Enyew B Assefa W Gezie A (2020). Socioeconomic effects of water hyacinth (Echhornia Crassipes) in Lake Tana, North Western Ethiopia. PLoS ONE 15(9): e0237668.

Firehun Y Struik E Lantinga and Taye T (2017). Occurrence and diversity of fungal pathogens associated with 
water hyacinth and their potential as biocontrol agents in the Rift Valley of Ethiopia, International Journal of Pest Management, 63 (4): 355-363.

Firehun Y Struik P Lantinga E and Taye T (2015). Adaptability of two weevils (Neochetina bruchi and Neochetina eichhorniae) with potential to control water hyacinth in the Rift Valley of Ethiopia. Crop Protection. 76 (1):75-82.

Firehun Y Struik P Lantinga E Taye T (2013). Joint use of insects and fungal pathogens in the management of water hyacinth (Eichhornia crassipes): perspectives for Ethiopia. J Aquat Plant Manage. 51 (1):109-121.

Frezina N (2013). Assessment and utilization of water hyacinth in the water bodies of Tamil Nadu. IJSRP 2 (1): 58-77.

Gopal B (1987). Water hyacinth, Elesevier Science Publishers, Amsterdam, pp. 471

Hill, M.P. and Coetzee, J.A., 2008. Integrated control of water hyacinth in Africa 1. EPPO bulletin, 38(3): 452457.

Julien M (2000). Biological control of water hyacinth with arthropods: a review to 2000. Biological and integrated control of water hyacinth Eichhornia crassipes. In: Julien M, Hill M and Jianqing D (Eds.), Proceedings of the Second Meeting of Global Working Group for the Biological and Integrated Control of Water Hyacinth, ACIAR Proceeding Number 102. Beijing, China, 9-12 October 2000, pp. 120-122.

Julien M and Griffiths M (1998). Biological Control of Weeds: A World Catalogue of Agents and their Target Weeds. $4^{\text {th }}$ edition. ABI Publishing, Oxford, pp. 90-96

Julien M Griffiths M and Wright A (1999). Biological control of water hyacinth. The weevils Neochetina bruchi and Neochetina eichhorniae: biologies, host ranges, and rearing, releasing and monitoring techniques for biological control of Eichhornia crassipes. ACIAR Monograph, pp. 60-87.

Martius V Zuccarini G and Smith D (1823). New genera and species of plants found in Brazil between 1817 and 1820.

Meerhoff M Mazzeo N Moss B and Rodríguez-Gallego L (2003). The structuring role of free-floating versus submerged plants in a subtropical shallow lake. Aquatic Ecology, 37 (4): 377-391.

Navarro L and Phiri G (2000). Water hyacinth in Africa and the Middle East: A survey of problems and solutions. Idrc.

Patel S (2012). Threats management and envisaged utilizations of aquatic weed Eichhornia crassipes: An overview. Rev Environ Sci Biotechnol 11: pp. 249-259.

Ray P (2006). Management of water hyacinth employing some insects and fungi. PhD Thesis, Jabalpur: R.D. University.

Rezene F (2005). Water hyacinth (Eichhornia crassipes): A review of its weed status in Ethiopia. Arem. 6 (1):105111.

Rezene F Taye T (2014). Alien plant species invasions in Ethiopia: challenges and responses.

Rhomela F Masangkay M Mabbayad O Timothy C Alan K (1999). Host range of Alternaria alternata causing leaf blight of Sphenoclea zeylanica. Can J Bot. 77 (1):103-112.

Senayit R Agajie T Taye T Adefires W Getu E (2004). Invasive Alien Plant Control and Prevention in Ethiopia. Pilot Surveys and Control Baseline Conditions.

Solms (1883). Eichhornia crassipes (Mart.) Solms in The International Plant Names Index Collaborators (2019). International Plant Names Index. Checklist dataset https://doi.org/10.15468/uhllmw accessed via GBIF.org on 2020-12-08.

Stasio D Beranek B and Schrimpf M (2018). Zooplankton-phytoplankton interactions in Green Bay, Lake Michigan: lower food web responses to biological invasions. Journal of Great Lakes Research, 44(5): 910923.

Stroud A. (1994). Water hyacinth (Eichhornia crassipes [Mart.] Solms) in Ethiopia. In: Rezene F. (ed.). Proc. $9^{\text {th }}$ Ann. Conf. EWSC 9-10 April 1991, Addis Ababa, Ethiopia; p. 7-16.

Taye T Rezene F Firehun Y Derje T Tamado T (2009). Review invasive weed research in Ethiopia. In: Abraham T, editor. Increasing crop production through improved plant protection: Vol. 2. Plant Prot. Soc. Eth., Addis Ababa, Ethiopia; p. 381-407.

Tegene S Ayele N (2014). Prevalence and intensity of water hyacinth infestation in the water bodies of rift valley Ethiopia. TJANRS 1 (1): 118-126.

Téllez T López E Granado G Pérez E López R and Guzmán J (2008). The water hyacinth, Eichhornia crassipes: an invasive plant in the Guadiana River Basin (Spain). Aquatic Invasions. 3(1): 42-53.

Téllez T López E Granado L Pérez A López R and Guzmán J (2008). The water hyacinth, Eichhornia crassipes: an invasive plant in the Guadiana River Basin (Spain). Aquatic Invasions, 3(1): 42-53.

Tewabe D (2016). Preliminary survey of water Hyacinth in Lake Tana, Ethiopia. Global Journal of Allergy, 1(1): 013-018.

Tewabe D Asmare E Zelalem W and Mohamed B (2017). Identification of impacts, some biology of water hyacinth (Eichhornia crassipes) and its management options in Lake Tana, Ethiopia. Net Journal of Agricultural 
Science, 5 (1): 8-15.

Tipping P Sosa A Pokomy N Foley J Schmitz D Lane S Rodgers L McCloud L Livingston-Way P and Nicholas G (2014). Release and establishment of Megamelus scutellaris (Hemiptera: Delphacidae) on water hyacinth. Fla. Entomol. 97 (2): 804-806.

Van T Ajuonu R Schade V Neuenschwander V Adit Ä and Lomer C (2010). Importation, releases, and establishment of Neochetina spp. (Col,:Curculionidae) for the biological control of water hyacinth, Eichhornia crassipes (Lil.: Pontederiaceae), in Benin,West Africa. Entomophaga, 39 (1): 179-188.

Wondie Z (2013). Assessment of water Hyacinth (Eichhornia crassipes (Mart) Solms) in relation to water quality, composition and abundance of plankton and macro-invertebrates in the north-eastern part of Lake Tana, Ethiopia. 